\title{
PEMBERDAYAAN PENGRAJIN TANAMAN HIAS KOMERSIAL
}

\author{
Alfi Nugroho ${ }^{1}$, Sujani $^{2}$, Ardiansyah Hendra Lukmana ${ }^{3}$ \\ ${ }^{1}$ Universitas Wijaya Putra \\ ${ }^{2}$ Universitas Wijaya Putra \\ ${ }^{3}$ Universitas Wijaya Putra
}

alfinugroho@uwp.ac.id, sujani@uwp.ac.id, hendra@uwp.ac.id

\begin{abstract}
Abstrak
Dalam perkembangan nya, banyak masyarakat yang mulai memerlukan layanan jasa jual beli yang memfasilitasi kebutuhan dalam bercocok tanam tersebut, hal ini di tangkap oleh beberapa kelompok dagang di lingkungan desa Pakal Sumberan, terutama di RT 05 RW 01. Di desa Pakal Sumberan RT 05 RW 01 saat ini sudah banyak di kenal oleh masyarakat yaitu sentra jual beli tanaman hias dan perlengkapan nya, para pedagang tersebut tergabung dalam kelompok paguyuban penjual tanaman hias, yang terdiri dari 15 anggota. Beberapa anggota di antaranya adalah ibu Supiati dan Ibu Kamto yang menempati di gang 03, permasalahan mitra yaitu, tidak adanya buku reverensi jenis tanaman, tidak adanya buku reverensi umum cara perwatan dari tanaman dan cara tata kelola pembukuan yang baik.

Solusi yang di tawarkan pada mitra adalah 3 hal, yaitu, Pembuatan buku literatur tanaman, Pembuatan buku literatur tentang metode perawatan tanaman hias, Pemberian pelatihan manajemen pencatatan keuangan sederhana, Dalam pelaksanaan kegiatan Program Pemberdayaan Masyarakat (PPM)ini, mitra akan berpartisipasi aktif dalam melengkapi literatur tanaman hias yang di buat, dengan harapan semakin lengkapnya literatur tersebut untuk menunjang proses pemasaran tanaman hias. Evaluasi dalam kegiatan ini di lakukan dalam beberapa bulan dengan meninjau jumlah pendapatan antara sebelum diadakan program dan setelah di lakukan pendampingan,.
\end{abstract}

Kata Kunci : Usaha mikro, tanaman hias, buku literatur

\section{PENDAHULUAN}

Dalam era Globalisasi, daerah lahan hijau semakin sempit, hal ini mengakibatkan banyak sekali masyarakat yang mulai sadar akan pentingnya bercocok tanam di lingkungan nya masing-masing yang di kenal sebagai Urban Farming, yaitu bercocok tanam di lahan sempit dengan memanfaatkan bahan yang tersedia di lingkungan. Yang paling popular yaitu pembuatan hidroponik, tambulampot atau taman vertikal (vertical garden)

Dalam perkembangannya, banyak masyarakat yang mulai memerlukan layanan jasa jual beli yang memfasilitasi kebutuhan dalam bercocok tanam tersebut, hal ini di tangkap oleh beberapa kelompok dagang di lingkungan desa Pakal Sumberan, terutama di RT 05 RW 01. Di desa Pakal Sumberan RT 05 RW 01 saat ini sudah banyak di kenal oleh masyarakat yaitu sentra jual beli tanaman hias dan perlengkapan nya, para pedagang tersebut tergabung dalam kelompok paguyuban penjual tanaman hias, yang terdiri dari 15 anggota. Beberapa anggota di antaranya adalah ibu Supiati dan Ibu Kamto yang menempati di gang 03 ,

Mitra 1 Ibu Supiati, merupakan warga dusun pakal sumberan gang 3 kecamatan pakal

Ekonomi, Sosial, dan Budaya

1337 
yang berdagang sejak tahun 2004, menempati stan dengan lebar sekitar $100 \mathrm{~m} 2$, dalam melakukan usahanya di bantu oleh 2 karyawan, kedua karyawan tersebut merupakan saudara dekat, hal ini dikarenakan belum bias menggaji orang lain.

Dalam melakukan usaha dagangnya, mitra tidak dapat melakukan banyak pengembangan bisnis ketika ada konsumen yang meminta beberapa tanaman khusus. Di samping tidak adanya pengetahuan yang luas tentang jenis tanaman yang di maksud ataupun cara perawatannya. mitra mengandalkan suplai dari pedagang distributor yang dating ke lokasi dagangnya, hal ini di karenakan tidak adanya relasi dari produsen langsung yang mengakibatkan terbatasnya jenis yang di jual oleh mitra

Dalam melakukan transaksi penjualan selama ini, mitra tidak pernah melakukan pencatatan, baik untuk persediaan barang atau buku kas, dalam wawancara lansung dengan mitra, kisaran omset per bulan sebesar $\mathrm{Rp}$ 4.000.000,-, data mendasar tentang permasalahan mitra 1 yaitu, tidak adanya buku reverensi jenis tanaman hias tidak adanya buku reverensi umum cara perwatan dari tanaman dan cara tata kelola pembukuan yang baik

Mitra 2 Ibu kamto,, merupakan warga dusun pakal sumberan gang 3 kecamatan pakal yang berdagang sejak tahun 1994, menempati stan dengan lebar sekitar $120 \mathrm{~m} 2$, dalam melakukan usahanya di bantu oleh 4 karyawan, kedua karyawan tersebut merupakan saudara dekat, hal ini dikarenakan belum bias menggaji orang lain.

Dalam pemasaran penjualan tanaman hiasnya, mitra hanya mengandalkan stok yang di kirim oleh distributor, hal ini mengakibatkan banyak peluang jual beli gagal di lakukan, karena kurangnya pengetahuan dari konsumen mengenai jenis tanaman hias yang bisa di sediakan oleh mitra.

Dalam melakukan transaksi penjualan selama ini, kisaran omset per bulan sebesar Rp 7.000.000,- akan tetapi mitra tidak pencatatan pasti tentang transaksi jual beli, data mendasar tentang permasalahan mitra 1 yaitu, tidak adanya buku reverensi jenis tanaman hias tidak adanya buku reverensi umum cara perwatan dari tanaman dan cara tata kelola pembukuan yang baik.

Dari kedua mitra tersebut, semua menggandalkan suplai penuh dari distributor yang dartang kepada mitra, baik untuk jumlah ataupun jenis tanaman yang akan di jual, hal ini di karenakan kurang adanya literatur yang mencakup jenis dan perawatan tanaman yang di minati masyarakat. Manaemen usaha yang di gunakan oleh mitra kesemuanya menggunakan metode konvensional untuk perhitungan laba rugi, tanpa meggunakan perhitungan keuangan yang tepat,

Permasalahan mitra

1)Tidak adanya literatur yang menampilkan gambar, nama dan jenis tumbuhan yang sering di perlukan oleh pembeli,

2) Tidak adanya literatur tentang metode perawatan dari tanaman

3)Tidak adanya metode pencatatan jual beli yang efisien

\section{METODE}

Berdasarkan analisis situasi dan rencana kerja yang dilakukan, maka ada perlu perioritas terahadap permasalahan yang di hadapi oleh mitra. Dari hasil pengamatan yang dilakukan oleh tim permasalahan mitra antaralain,

1)Tidak adanya reverensi jenis tanaman hias,

2)Tidak adanya literatur metode perawatan tanaman hias,

3)Mitra belum melakukan administrasi pembukuan

Berdasarkan permasalahan mitra di atas, tentu permasalahan yang di hadapi perlu di berikan penyelesaian. Untuk itu solusi yang di tawarkan oleh tim adalah pemberian buku literatur tanaman hias dan pelaksanaan pelatihan pembukuan sederhana.

Tabel 1. (metode pelaksanaan)

\begin{tabular}{lll}
\hline $\begin{array}{l}\text { Aspek } \\
\text { permasalahan }\end{array}$ & $\begin{array}{l}\text { permasalahan di } \\
\text { kedua mitra }\end{array}$ & Metode pelaksanaan \\
\hline pemasaran & $\begin{array}{l}\text { tidak adanya } \\
\text { literatur tentang } \\
\text { jenis tanaman hias }\end{array}$ & $\begin{array}{l}\text { dilakukan } \\
\text { pendampingan dan } \\
\text { evaluasi tentang } \\
\text { literatur tanaman hias }\end{array}$ \\
& $\begin{array}{l}\text { kurangnya } \\
\text { pengetahuan tentang } \\
\text { cara perawatan } \\
\text { tanaman hias }\end{array}$ & $\begin{array}{l}\text { pengadaan manual } \\
\text { book tentang } \\
\text { perawatan tanaman } \\
\text { hias secara umum }\end{array}$ \\
& $\begin{array}{l}\text { tidak pernah } \\
\text { membukukan }\end{array}$ & $\begin{array}{l}\text { Pelatihan dan } \\
\text { evaluasi } \\
\text { menggunakan aplikasi }\end{array}$ \\
& laporan keuangan & SiKecil berbasis \\
& & Android
\end{tabular}

Ekonomi, Sosial, dan Budaya 
Dalam pelaksanaan mitra akan berpartisipasi aktif dalam melengkapi literatur tanaman hias yang di buat, dengan harapan semakin lengkapnya literatur tersebut untuk menunjang proses pemasaran tanaman hias.

Evaluasi dalam kegiatan ini di lakukan dalam beberapa bulan dengan meninjau jumlah pendapatan antara sebelum di adakan program dan setelah di lakukan pendampingan,

\section{HASIL DAN PEMBAHASAN}

Adapun Hasil yang dicapai dari pelatihan dan pendampingan dapat kami jelaskan sebagai berikut :

1) Terhadap masalah pemasaran dilakukan Pembuatan buku literatur tanaman hias, dan buku tentang perawatan tanaman, hal ini berdampak positif dalam proses jual beli di mitra 1 dan mitra 2, dengan pemberian buku literatur tanaman hias, dan buku tentang perawatan tanaman, kedua mitra dengan mudah menyampaikan informasi kepada pembeli tentang jenis-jenis tanaman hias yang dapat di sediakan di kedua mitra dan juga informasi tentang cara perawatan dari tanaman hias.

Tabel 2. (Pendapatan Bersih mitra 1 dan 2)

\begin{tabular}{ccc}
\hline 1) & & \\
\hline Bulan & Mitra 1 & Mitra 2 \\
\hline Mei & Rp. 4.340 .000 & Rp. 6.980.000 \\
Juni & Rp. 4.400.000 & Rp. 7.100.000 \\
Juli & Rp. 5.100.000 & Rp. 8.250.000 \\
Agustus & Rp. 5.950.000 & Rp. 9.250.000 \\
\hline
\end{tabular}

Dari data yang diperoleh dari pencatatan keuangan, terdapat kenaikan pendapatan dari kedua mitra antara 16 sd $17 \%$ pada bulan ke 2 setelah di berikan pendampingan dan evaluasi menggunakan buku literatur tanaman hias, dan buku tentang perawatan tanaman hias.

2) Terhadap masalah Administrasi pembukuan, mitra di berikan pelatihan dan Pendampingan dalam meningkatkan kemampuan Administrasi Berbasis IT berupa pembukuan sederhana menggunakan program SiKecil yang di akses menggunakan HP Android kedua mitra. Hasil yang dicapai dalam pelatihan ini cukup berhasil, artinya setelah mendapat Pelatihan dan Pendampingan Administrasi berbasis IT baik Mitra
1 dan Mitra 2 dapat mengaplikasikan program SiKecil untuk pengerjaan Pembukuan sederhana

\section{KESIMPULAN}

Setelah Pelaksanaan Pengabdian Masyarakat maka dapat disimpulkan Sebagai berikut:

1) dari hasil kegiatan, berdampak pada bulan ke 2 untuk hasil penjualan tanaman hias yang berkisar antara 16 sd $17 \%$ dibandingkan dengan sebelumnya. Dan dari sisi mitra dapat menambah pengetahuan tentang jenis dan standart tata cara perawatan tanaman hias yang sering di minati oleh masyarakat

2) sudah adanya pencatatan pembukuan yang baik dengan menggunakan aplikasi pencatatan keuangan sederhana SiKecil berbasis aplikasi Android, hal ini mempermudah mitra untuk memantau hasil penjualan dan pengeluaran.

\section{SARAN}

Dari pelaksanaan pengabdian masyarakat maka di sarankan sebagai berikut, 1) pengembangan literatur tanaman hias yang sudah di berikan kepada mitra, 2) penyesuaian tentang konten isi dari tata cara perawatan tanaman hias(tidak secara global), 3) untuk pencatatan keuangan di sarankan kepada mitra untuk dilengkapi tentang data stok dan tidak hanya di gunakan untuk mengisi jual beli saja

\section{UCAPAN TERIMAKASIH}

Ucapan terima kasih disampaikan kepada Universitas Wijaya Putra yang telah memberikan kesempatan kepada penulis untuk melakukan pengabdian kepada masyarakat di Kecamatan Pakal Surabaya

\section{REFERENSI}

Soegoto, Eddy Soeryanto, (2009). Enterpreneurship Menjadi Pebisnis Ulung. Jakarta: PT Elex Media Komputindo.

Subanar, (1992). Permasalahan Usaha Kecil Menengah. Surabaya: Dinas/Kanwil Perindustrian Jawa Timur. 
Philip Kotler, Manajemen Pemasaran Analisis, Perencanaan, Implementasi Dan Pengendalian, Lembaga Penerbit Fakultas Ekonomi Univ. Indonesia, Edisi 15, Jakarta, 2005
Lee J. Krajewski Dan Larry P. Ritzman, Operations Management Strategy AndAnalysis, Addison Wesley Publishing Company, 2002 